\title{
Концептуальні підходи здоров'я- формуючої діяльності в процесі адаптивного фізичного виховання дітей з вадами слуху
}

\author{
Олена Маслова
}

\author{
Національний університет фізичного виховання і спорту України, Київ, Україна
}

\begin{abstract}
Анотація. Вагомість здоров'я як найвищої загальнолюдської цінності та головного чинника досягнення успіху і благополуччя дозволяє визначити здоров'яформуючу компетентність як ключову в сучасній системі освіти, особливо інклюзивної. Мета. Визначення, узагальнення та обгрунтування концептуальних підходів здоров'ясрормуючої діяльності в процесі адаптивного фізичного виховання дітей з порушеннями слуху як складової методологічної основи розробленої нами концепції. Методи. Аналіз та синтез даних науково-методичної літератури, ресурсів мережі Інтернет, абстрагування, контент-аналіз теоретичних та методичних робіт, конкретизація та класифікація, прогнозування. Результати. Представлені у статті результати наукових досліджень продемонстрували широкий спектр наукових доробок у напрям формування здоров'я сучасної молоді, заохочення до запровадження у повсякденне життя нових фрорм поведінки, корисних для здоров'я, а отже, успішного виховання здорового покоління. Особливе значення у формуванні здоров'я та здорового способу життя молодого покоління зі встановленими порушеннями функцій систем організму надається змісту освіти, побудованого в руслі методологічних підходів наукового пізнання.

Ключові слова: концепція, підхід, методологія, здоров'яформуюча діяльність, порушення слуху, школярі, діти.
\end{abstract}

\section{Olena Maslova}

\section{CONCEPTUAL APPROACHES TO HEALTH-FORMING ACTIVITY IN THE PROCESS OF ADAPTIVE PHYSICAL EDUCATION OF CHILDREN WITH HEARING IMPAIRMENTS}

\begin{abstract}
The importance of health as the highest universal value and the main factor in achieving success and well-being allows defining health-promoting competence as the key in the modern education system, especially inclusive. Objective. Definition, generalization and substantiation of conceptual approaches of health-forming activity in the process of adaptive physical education of children with hearing impairments as a component of the methodological basis of the concept developed by us. Methods. Analysis and synthesis of data of scientific and methodical literature, Internet resources, abstraction, content analysis of theoretical and methodical works, concretization and classification, forecasting. Results. The results of scientific research presented in the article demonstrated a wide range of scientific achievements in the direction of shaping the health of modern youth, encouraging the introduction into everyday life of new behaviors useful for health, and thus the successful upbringing of a healthy generation. Particular importance in the formation of health and a healthy lifestyle of the younger generation with established disorders of the body's systems is given to the content of education, built in line with the methodological approaches of scientific knowledge.

Keywords: concept, approach, methodology, health-promoting activity, hearing impairment, schoolchildren, children.
\end{abstract}


зичного виховання» (номер держреєстрації 0116U001620).

Мета дослідження - визначення, узагальнення та обгрунтування концептуальних підходів здоров'яформуючої діяльності в процесі адаптивного фізичного виховання дітей 3 вадами слуху як складової методологічної основи розробленої нами концепції.

Методи дослідження: аналіз та синтез даних науково-методичної літератури, ресурсів мережі Інтернет 3 питань необхідності формування ціннісного ставлення до власного здоров'я у дітей з порушеннями слуху та місця здоров'яформуючих технологій у процесі адаптивного фізичного виховання; абстрагування, контентаналіз теоретичних та методичних робіт, конкретизація та класифікація.

Результати дослідження та їх обговорення. В процесі розгляду питання методологічної розробки та впровадження засобів і методів фрормування здоров'я певної категорії населення нами було розроблено концепцію здоров'ясрормуючих технологій у процесі адаптивного фрізичного виховання дітей шкільного віку з порушеннями слуху [4].

Основу запропонованої нами концепції становив симбіоз концептуальних підходів різних рівнів методології наукового пізнання (рис. 1):

- перший (вищий) - фрілософський, або рівень фрілософської методології, що включає загальні принципи пізнання і категоріальний лад науки в цілому;

- другий - загальнонаукова методологія, або рівень методології загальнонаукових принципів дослідження;

- третій - конкретно-наукова методологія, або рівень конкретнонаукової методології, що являє собою сукупність методів, принципів дослідження і процедур, які застосовуються у тій чи іншій спеціальній науковій дисципліні;

- четвертий - технологічна методологія, або рівень методик і техніки дослідження, тобто набір процедур, що забезпечують отримання достовірного емпіричного матеріалу і його первинну обробку, після якої він може включатися в масив наукового знання $[1,6]$.

Під час визначення основних положень концепції здоров'яформуючих технологій у процесі адаптивного фізичного виховання дітей шкільного віку з порушеннями слуху ми спирались на фрілософські вчення (напрями), які слугують методологією різних наук, у тому числі й педагогіки:

- екзистенціалізму як фрілософської основи індивідуалізації навчання, де цінність знань визначається тим, наскільки вони важливі для особистості учня, свобода у системі засвоєння знань;

- прагматизму (неопрагматизму) як фрілософсського обґрунтування інструменталізації процесу навчання на основі власної активності учнів, її розвиток і стимуляція, самоствердження особистості;

- позитивізму (неопозитивізму) як філософського центру гуманізму, де головна увага повинна приділятись розвитку інтелекту, формуванню раціонально мислячої людини;

- біхевіоризму (необіхевіоризму) як фрілософської основи технократичного виховання з урахуванням найновіших досягнень науки про людину, використання сучасних методів дослідження її поведінки;

- діалектичного матеріалізму як філософського вчення про найбільш загальні закони руху і розвитку природи, суспільства і мислення, що детермінований зовнішніми обставинами $[1,6]$.

Зміст методології першого рівня становлять загальні принципи пізнання, ключові категорії науки в цілому, що визначаються загальними філософськими концепціями, які розглядають конкретну наукову проблему. Вчені виділяють окремі фрілософські підходи, які лягли в основу визначення напряму нашого дослідження у системі педагогіки, зокрема виховання [6].

Ідеалістичний підхід дозволив нам виокремити у процесі виховання пріоритетність на духовно-моральні цінності й позитивну глибинність суті в кожній людині, що характеризується осмисленням самовдосконалення як суто внутрішньої активності, спря- мованої на розвиток духовності, збагачення внутрішнього світу особистості шляхом актуалізації її потенційних сил, нехтування активною діяльнісною установкою на вдосконалення світу, визнання самоцінності самовдосконалення [3, 6].

Позитивістський підхід зорієнтував нас на визначення людини одночасно як суб'єкта, так і об'єкта педагогічного процесу: «суб'єктність» людини обумовлена її інтелектуальною еволюцією, яка забезпечує активність у пізнавальній діяльності, а «об'єктність» походить із ідеї «прогресу як істинно основного догмата людського життя» [6].

Матеріалістичний підхід дав можливість розглянути психологопедагогічні явища педагогіки в діалектичній єдності, тобто дотримання трьох законів діалектики: єдності та боротьби протилежностей, переходу кількісних змін в якісні, заперечення заперечення [6].

Еклектичний підхід сприймався нами як змішання, з'єднання різнорідних, тобто різних за походженням елементів, стилів, ідей, поглядів у педагогіці, зокрема у педагогіці виховання.

Аналіз існуючих напрацювань науковців дав нам змогу визначити підходи загальнонаукового рівня методології концепції здоров'яформуючих технологій у процесі адаптивного фізичного виховання дітей шкільного віку з порушеннями слуху. Так, історичний підхід обґрунтував основну ідею нашого дослідження - проблема здоров'я, що здавна привертала пильну увагу людини. Історія розвитку людства, характерними символами якої завжди було прагнення людини до прогресу, пізнання законів природи і соціуму, свідчить про те, що в усіх суспільно-історичних формаціях незмінним залишалося прагнення людей жити якомога довше і не страждати від хвороб, народжувати і виховувати життєздатне потомство [4, 13].

у контексті нашого дослідження для утвердження його актуальності ми звернулись до термінологічного підходу для визначення раціональних трактувань у питанні здоров'яформування таких понять, 


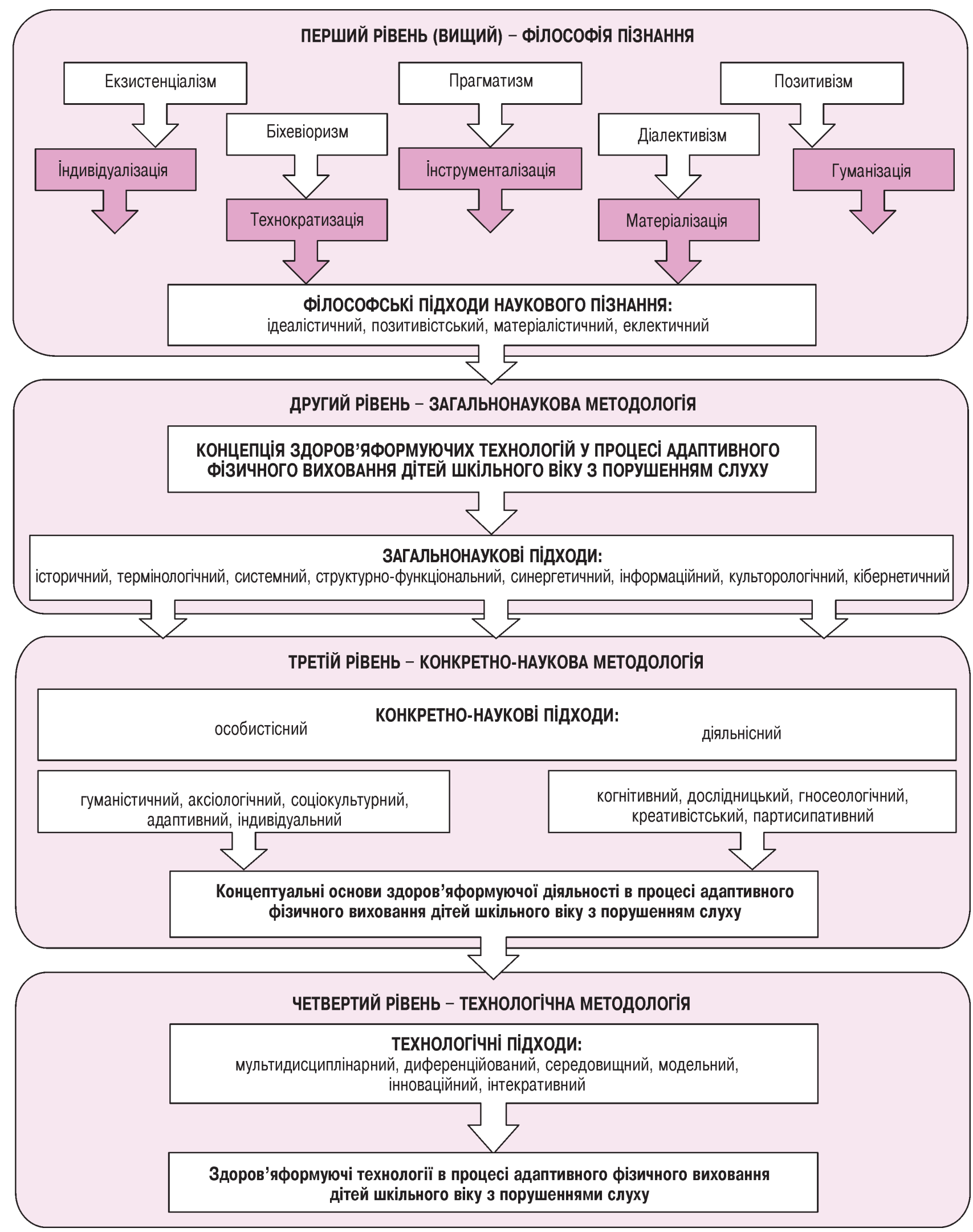

Рисунок 1 - Система методологічних підходів концепції здоров'яформуючих технологій у процесі адаптивного фізичного виховання дітей шкільного віку з порушеннями слуху 
як «здоров'я», «розвиток», «фрормування», «виховання», та розробки термінологічного апарату концепції здоров'яформуючих технологій у процесі адаптивного фрізичного виховання дітей шкільного віку з порушеннями слуху [7].

Системний підхід як методологічний напрям у науці, основне завдання якого полягає в розробці методів дослідження і конструювання складноорганізованих об'єктів, дав нам змогу встановити основні принципи корекційно-розвиваючої роботи і розширити межі її ефективності, спланувати, узгодити послідовне застосування різних форм і методів формування здоров'я для централізованого впливу на систему інтеграції дитини у соціум $[7,12]$.

Структурно-фрункціональний підхід авторської концепції дозволив нам чітко виділити в системних об'єктах формування здоров'я дітей 3 порушеннями слуху в процесі адаптивного ффізичного виховання структурних елементів (компонентів) і визначити їх ролі (функції) у системі [7].

Синергетичний підхід сприяв розробці поглядів на систему формування здоров'я дітей з порушеннями слуху в процесі адаптивного фрізичного виховання як на окремий живий педагогічний процес, де кореляція педагогічного впливу відбувається під дією потреб особистості дитини, яка розвивається, долаючи кризи, і призводить до резонансу та перетворює педагогічний вплив на максимально ефективний процес. Зміст синергетичного підходу запропонованої нами концепції розглядає компетентність як феномен, що може формуватися в умовах самоорганізаційного впливу, а становлення та розвиток особистості дитини 3 порушенням слуху є ефрективним у разі врахування тенденцій та закономірностей їі самоорганізації $[7,11]$.

Пізнавальні можливості інфоормаційного підходу для дослідження полягали у тому, що предмет дослідження ми вивчали у контексті інформації та її численних виявів щодо використання пізнавальних можливостей інформаційної теорії, застосування методів, засобів, організаційних форм і технологій, вироблених інформати- кою, для визначення специфічних рис формування здоров'я дітей 3 порушеннями слуху в процесі адаптивного фрізичного виховання [6].

Культурологічний підхід, з огляду на широту визначення поняття «культура» та пізнавальні можливості культурології, створив для нас можливість вивчити об'єкти і явища формування здоров'я дітей з порушеннями слуху як культурологічний феномен, особливо для забезпечення багатофракторності механізмів функціонування та зв'язку «соціальної» і «культурної» сорер сучасного суспільства $[6,15]$.

Кібернетичний підхід дозволив нам побачити в системі формування здоров'я дітей з порушеннями слуху в процесі адаптивного фізичного виховання складні процеси, які потребують управління, виділити об'єкти, конструктивно вказати на мету управління, розробити його цикли під час встановлення вихідних, проміжних і підсумкових станів об'єкта, виявити систематичний зворотний зв'язок та реалізувати корегувальні програми педагогічних впливів $[6,10]$.

Підходами конкретно-наукового рівня методології формування здоров'я дітей 3 порушеннями слуху в процесі адаптивного фрізичного виховання стали особистісний та діяльнісний, що неодноразово були апробовані іншими дослідниками в процесі фуннціонування системи фізичного виховання, а деякі - адаптовані до вимог процесу фрізичного виховання і розглядались нами як необхідна складова авторської концепції $[6,14]$.

Так, особистісний підхід у нашому досліджені подає особистість дитини як унікальну і відкриту соціальну систему 3 властивими їй можливістю духовної самоактуалізації у відносинах до оточуючого світу і самого себе в процесі міжособистісних взаємодій, здатністю розвиватися і ставати творчою індивідуальністю, формуватися в діяльності, спілкуванні, пізнанні і самоосвіті. Компонентами даного підходу стали:

- гуманістичний - розкриває необхідність процесу адаптивного фрізичного виховання бути емоційно насиченим, приносити корисні результати, викликати почуття природного за- доволення і мотивувати до фрізичного самовдосконалення;

- аксіологічний - розглядає мету процесу виховання, в тому числі адаптивного фрізичного виховання, у сприйнятті людини як найвищої цінності суспільства, формування у школярів розуміння здоров'я як найвищої цінності, спонукання до необхідності піклуватися про своє здоров'я, починаючи 3 самого дитинства і продовжуючи протягом навчання у школі та подальшого свого життя;

- соціокультурний - доповнює зміст адаптивного фрізичного виховання створенням оптимальних умов для розвитку талантів, розумових і фізичних здібностей особистості дитини, виховання високих моральних якостей, підтримання традицій громадян нашої держави, здатних до свідомого суспільного вибору, збагачення на цій основі інтелектуального, творчого, культурного потенціалу українського народу, формування патріотизму, національної самосвідомості;

- адаптивний - актуалізує специфріку адаптивного фрізичного виховання у напрямі підтримання гомеостазу організму дитини, організації адекватної мікросоціальної взаємодії, оптимального фрормування психофрізіологічних співвідношень і збереження її фізичного здоров'я;

- індивідуальний - акцентує увагу адаптивного фрізичного виховання на формуванні постулатів індивідуального здоров'я особистості дитини: чим повніше індивіду вдається реалізовувати свій біологічний, психічний, соціальний і духовний потенціал, тим помітніше підвищується рівень його здоров'я $[7,8]$.

Згідно з діяльнісним підходом запропонованої нами концепції, процес адаптивного фрізичного виховання будується на основі формування практичного досвіду, який набувається школярами в ході активної асиміляції різних видів власної діяльності, відображених у таких компонентах:

- когнітивний - характеризує ступінь засвоєння особистістю знань про своє здоров'я, розуміння ролі здоров'я у власній життєдіяльності, практичне ознайомлення 3 негатив- 
ними (ушкоджуючий) та позитивними (зміцнюючий) впливами на здоров'я;

- дослідницький - вимагає від процесу адаптивного фрізичного виховання розвитку дослідницьких навичок та залучення до науково-пропагандистської діяльності усіх зацікавлених особистостей як дієвого засобу їх виховання як здорової та загартованої людини, вироблення ряду прикладних навичок, необхідних їм у повсякденному житті, залученням до навчально-дослідницької діяльності, що сприяє розвитку мислення і творчої думки;

- гносеологічний - реалізує мету формування здоров'я в процесі адаптивного фрізичного виховання через стимуляцію пізнавальної діяльності особистості дитини, підтримання постійного прагнення до набуття нових знань та вдосконалення вже набутих;

- креативістський - полягає у розвитку творчої індивідуальності особистості учнів, у творчому підході до здійснення ними здоров'яфрормуючої діяльності, вдосконалення їх творчих якостей та здібностей у питанні формування здоров'я, вирішенння проблеми сходження до власної творчої індивідуальності за рахунок апробації інноваційних засобів адаптивного фізичного виховання;

- партисипативний - активізує взаємодією учасників освітнього процесу у напрямі самоуправління здоров'яформуючою діяльністю і передбачає безпосередню участь школярів у прийняті рішень спільно 3 учителем щодо способів, фрорм здоров'яформуючої діяльності на умовах співробітництва, неформального делегування повноважень 3 метою саморозвитку у процесі адаптивного фрізичного виховання $[7,11,12]$.

Виокремлення технологічних підходів четвертого рівня наукового пізнання розширює уявлення про суть поняття «здоров'ясоормуючі технології» і дає змогу розуміти його як системний метод програмування цілей, конструювання змісту, прийомів, засобів навчання й виховання, спрямованих на підвищення рівня індивідуального здоров'я, формування здоров'ярозвиваючої компетентності та створення здоров'язберігаючого освітнього середовища в навчально му закладі у процесі адаптивного фрізичного виховання за умов здійснення моніторингу стану здоров'я суб'єктів освітнього процесу. Цю категорію наукових підходів становлять:

- мультидисциплінарний - характеризується зв'язком і взаємодією з іншими науками про людину, різноманіттям способів впливу на здоров'я, його фрормування, збереження, зміцнення та відновлення;

- диференційований - висвітлює організаційно-методичні основи здійснення здоров'яформуючої діяльност у процесі адаптивного фрізичного виховання відповідно до групових особливостей школярів;

- середовищний - розглядається як засіб пізнання й розвитку особистості дитини та $є$ системою взаємодій із середовищем, яке водночас перетворюється на засіб діагностики проєктування і продукування виховного результату у напрямі фрормування власного здоров'я

- модельний - відображає характерні риси реального педагогічного процесу і на основі ключової ідеї дослідження та визначених методологічних підходів відбувається моделювання необхідного стану системи що вивчається, зокрема теоретичних знань і практичних навичок здійснення здоров'ясрормуючої діяльності в процесі адаптивного ффізичного виховання;

- інноваційний - забезпечує європейську якість вищої освіти, відхід від традиційної системи навчання і виховання, перехід до навчальновиховного процесу інноваційного типу 3 новими технологіями і новим змістом, автономізацію освітніх закладів, розвиток варіативності освіти, інтенсифікацію змісту освіти, включення пріоритету формування здоров'я серед контингенту молодого покоління у процес їх виховання;

- інтегративний - укладає в єдину концептуальну основу вивчення проблематики формування здоров'я дітей 3 порушеннями слуху у процес адаптивного фрізичного виховання [5, 7, 9].

Дискусія. Дослідження теоретичних і практичних основ фрормування здоров'я сучасного молодого покоління в умовах інклюзивної освіти виявило едективність дотриманням ряду педагогічних умов, серед яких важливими є такі: цілісність, безперервність процесу опанування знань і набуття компетентностей організації здорової життєдіяльності учнів; використання предметного поля навчальних дисциплін, зміст яких становить методологічну, теоретичну і прикладну основу формування здоров'я; орієнтація процесу навчання, складником якого $€$ засвоєння досвіду формування здоров'я, на суб'єктну позицію школяра як носія індивідуального досвіду і способу життя; мотиваційне забезпечення діяльності учня, що ґрунтується на пізнавальній активності, діалогічності, креативності, практичній значущості навчального процесу для кожного суб'єкта діяльності та вільному виборі його позиції; залучення школярів до діяльності, яка моделює їх майбутню професійну працю; реалізація у процесі формування здоров'я дітей з порушеннями слуху принципів пріоритетності гуманістичних цінностей, демократизму, індивідуалізації, самопізнання та саморозвитку.

На нашу думку, фрормування здоров'я у сучасних дітей має за кінцеву мету вдосконалення умов життя і життєдіяльності на основі виховання і освіти, які включають вивчення свого організму і своєї особистості, засвоєння гігієнічних навичок, знання фракторів ризику і вміння реалізувати на практиці комплекс засобів і методів долучення до цінностей здорового способу життя

Здійснюючи цілеспрямовану і свідому діяльність 3 оздоровлення свого організму, створюючи здорове середовище проживання, вибудовуючи раціональну систему життєдіяльності, дитина з порушенням слуху впливає на обставини повсякденного життя, створює основу для ефективної навчальної діяльності і самореалізації у майбутній професії.

За своїм цільовим призначенням формування здоров'я у процесі адаптивного фізичного виховання реалізує принцип антропоцентризму, компетентнісний і особистісно-діяльнісний підходи, в основі яких - найбільш 
ефективне використання науково обґрунтованих знань про здоров'я людини, засоби і методи його збереження і зміцнення в режимі конкретних умов життєдіяльності для максимально повної самореалізації інтересів, потреб, запитів та можливостей щодо майбутньої соціальної інтеграції.

Загалом ці підходи ґрунтуються на необхідності забезпечити єдність провідних функцій освіти (гностичної, творчої, аксіологічної, комунікативної), які взаємодоповнюють одна одну і тим самим становлять функціональну основу педагогічного процесу - впорядкованої системи освітніх і виховних впливів, яка дає змогу школяру з порушенням слуху цілеспрямовано, послідовно й усвідомлено опановувати знання, набути загальних і предметних компетентностей, не завдаючи шкоди своєму здоров'ю.

Висновки. Отримання наукових знань значною мірою залежить від підходу, яким послуговується дослідник, вивчаючи об'єкт пізнання. Цей підхід визначає система методологічних засад і принципів.

Вихідним кроком кожного педагогічного дослідження $€$ визначення теоретико-методологічної бази, на основі якої виконується всебічний аналіз проблеми, вибудовуються теоретичні та практичні положення, обґрунтовуються концептуальні ідеї, педагогічні умови, розробляються освітні технології, даються методичні рекомендації, пропозиції тощо.

Нами визначено, систематизовано і розкрито основні методологічні підходи здійснення здоров'яформуючої діяльності школярів з вадами слуху у процесі адаптивного фізичного виховання.

Перспективи подальшого дослідження полягають у науковому обґрунтуванні основних теоретичних положень авторської концепції та експериментальної апробації її методичної основи.

Конфлікт інтересів. Автор заявляє, що відсутній будь-який конфлікт інтересів.

\section{ЛІТЕРАТУРА}

1. Кашуба ВО, Маслова ОВ, Ричок ТМ. Технологія корекції фрізичного стану школярів з вадами слуху в процесі фрізичного виховання.
Теорія і методика фрізичного виховання і спорту [Інтернет] 2018;2:42-48. Доступно: http://tmfvsjournal.uni-sport.edu.ua/article/view/141793 DOI: https://doi.org/10.32652/tmfvs.2018.1.42-48

2. Кашуба В, Футорний C, Хабінець Т, Лопацький С. K вопросу повышения эффектив ности физического воспитания занимающих ся физическими упражнениями с использованием технологических инноваций. Молодіжний науковий вісник Східноєвропейського національного університету імені Лесі Українки. [Інтернет] 2018;27:46-53. Доступно: https:// sportvisnyk.eenu.edu.ua/index.php/sportvisnyk/ article/view/134

3. Маслова ОВ, Гопей ММ. Особливості фізичного розвитку і фрізичної підготовленості школярів 3 вадами слуху та перспективи їх корекції засобами спортивних ігор. Спортивний вісник Придніпров'я. 2016;2:139-146.

4. Маслова ОВ, Гопей ММ. Обґрунтування необхідності розробки інноваційних технологій для оптимізації процесу фрізичного виховання дітей 3 вадами слуху. Теорія і методи ка фізичного виховання і спорту. [Інтернет] 2017;3:78-85. Доступно: http://tmfvs-journal.unisport.edu.ua/article/view/120823 DOI: https://doi org/10.32652/tmfvs.2017.3.78-85

5. Маслова ОВ, Савченко ЮО, Богдано вич ЛВ, Голуб ЮЮ, Шумійчук ВВ. Ендоекологічн підходи формування здоров'я дітей з вадами слуху у процесі адаптивного фрізичного вихо вання. Науковий часопис НПУ імені М. П. Драгоманова. Серія 15: Науково-педагогічні проблеми фрізичної культури (фрізична культура і спорт). 2018;6(100):59-62.

6. Форостян ОІ. Теоретико-методичні засади адаптивного фрізичного виховання підлітків 3 порушеннями слуху. Наука і освіта. 2015:5:128-133.

7. Футорный СМ. Здоровьесберегающие технологии в процессе физического воспита ния студенческой молодежи. Киев: Саммиткнига; 2014. 296 с.

8. Футорний СМ, Шкребтий ЮМ, Маслова ЕВ. Тенденции формирования здорового образа жизни современного молодого поколения Науковий часопис НПУ імені М. П. Драгома нова. Серія 15: Науково-педагогічні проблеми фізичної культури (фізична культура і спорт). 2015;9(64):89-91.

9. Goncharova NM. Preconditions of the concept of health forming technologies in the process of physical education of primary school-aged children. Health, sport, rehabilitation. [Internet] 2018;4(2):22-27. Available from: http://sportsscience.org/index.php/health/article/view/761 DOI: http://dx.doi.org/10.34142/ HSR.2018.04.02.02

10. Kashuba V, Goncharova N. Optimization of the process of primary school age children adaptation: practical expertise. Journal of Education Health and Sport. [Internet] 2018;8(7): 665-674. Available from: http://www.ojs.ukw.edu.pl/index php/johs/article/download/6580/8288 DOI http:// dx.doi.org/10.5281/zenodo.2561331 http://ojs ukw.edu.pl/index.php/johs/article/view/6580

11. Kashuba Vitaliy, Maslova Olena. Prerequisites for the development of the concept of health-forming technologies in the process of adaptive physical education of school-age children with hearing impairment. Journal of Education, Health and Sport formerly Journal of Health Sciences. [Internet] 2017;3:824-834. Available from: http://www.ojs.ukw.edu.pl/index.php/johs/ article/view/5530 DOl: http://dx.doi.org/10.5281/ zenodo.1252439
12. Kashuba V, Goncharova N, Butenko $H$ Practical implementation of the concept of healthforming technologies into the process of physical education of primary school age children. Journal of Education, Health and Sport. [Internet] 2018;8(6): 469-477. Available from: http://www ojs.ukw.edu.pl/index.php/johs/article/view/6579 doi: 10.22141/2224-0551.13.1.2018.127059

13. Kashuba V, Futornyi S, Andrieieva O, Goncharova N, Carp I, Bondar O \& Nosova N. Optimization of the Processes of Adaptation to the Conditions of Study at School as a Component of Health Forming Activities of Primary School-Age Children Journal of Physical Education and Sport (JPES) [Internet] 2018;18(4):2515. Available from: http:// efsupit.ro/images/stories/decembrie2018/Art\%20 377.pdf DOI:10.7752/jpes.2018.04377

14. Futornyi S. Actual issues of improving the process of students physical education through the application of modern health-saving technologies. Молодіжний науковий вісник Східноєвропейського національного університету імені Лесі Українки. Фізичне виховання і спорт. 2014;14:26-30.

15. Futornyi Serhii, Maslova Olena, Shmatova Olena, Osadcha Oksana, Rychok Tatiyana, Hopey Maksym, Tarnavskiy Artur Modern aspects of the ecological culture implementation in the physical education process of different population groups. Journal of Physical Education and Sport (JPES). [Internet] 2020 Jen [cited 2020 March 2]; 20(1):348-353. Available from: https://efsupit. ro/images/stories/februarie2020/Art\%2049.pdf DOI:10.7752/jpes.2020.s1049

\section{LITERATURE}

1. Kashuba VO, Maslova OV, Rychok TM. Technology of correcting physical condition of schoolchildren with hearing impairments in the process of physical education. Teoriia i metodyka fizvykhovannia i sportu. [Internet] 2018;2:42-48. Available: http://tmfvs-journal.uni-sport.edu.ua/ article/view/141793 DOI: https://doi.org/10.32652/ tmfvs.2018.1.42-48

2. Kashuba V, Futorny $S$, Khabinets $T$, Lopatskyi S. To the question of increasing the effectiveness of physical education of those practicing physical exercises with usage of technological innovations. Molodizhnyi naukovyi visnyk Skhidnoievropeyskoho universytetu im. Lesi Ukrainky. [Internet] 2018;27:46-53. Available: https://sportvisnyk.eenu.edu.ua/index.php/ sportvisnyk/article/view/134

3. Maslova OV, Hopay MM. Features of the physical development and physical fitness of schoolchildren with hearing disorders and the prospects of their corrections by sports games. Sportyvnyi visnyk Prydniprovia. 2016;2:139-146.

4. Maslova OV, Hopay MM. Substantiatin the need for innovative technologies to optimize the process of physical education of children with hearing disorders. Teoriia i metodyka fizvykhovannia i sportu. [Internet] 2017;3:78-85. Available: http://tmfvs-journal.uni-sport.edu.ua/ article/view/120823 DOI: https://doi.org/10.32652/ tmfvs.2017.3.78-85

5. Maslova OV, Savchenko IO, Bohdanovych LV, Holub II, Shumiychuk VV. Endoecological approaches to the development of the health of children with hearing impairments in the process of adaptive physical education. Naukovyi chasopys Natsionalnoho pedahohichnoho universytety imeni M. P. Drahomanova. 2018;6(100):59-62 
6. Forostian 0I. Theoretico-methodical bases of adaptive physical education of teenagers with hearing disorders. Nauka i osvita. 2015;5:128-133.

7. Futorny SM._Health-saving technologies in the process of physical education of student youth. Kiev: Sammit-kniga; 2014. 296 p

8. Futorny SM, Shkrebtiy YM, Maslova EV. Trends of forming healthy life style of modern young generation. Naukovyi chasopys Natsionalnoho pedahohichnoho universytety imeni $M$. P Drahomanova. 2015;9(64):89-91

9. Goncharova NM. Preconditions of the concept of health forming technologies in the process of physical education of primary school-aged children. Health, sport, rehabilitation. [Internet] 2018;4(2):22-27. Available from http://sportsscience.org/index.php/health/article/view/761 DOl: http://dx.doi.org/10.34142/ HSR.2018.04.02.02

\section{ІНФОРМАЦІЯ ПРО АВТОРА}

Маслова Олена Володимирівна ORCID.0RG/0000-0003-4926-7681,0205@ukr.net

Національний університет фрізичного виховання і спорту України: вул. Фізкультури, 1, Київ, 03150, Україна.

\section{INFORMATION ABOUT AUTHOR}

Maslova Olena ORCID.0RG/0000-0003-4926-7681,0205@ukr.net

National University of Ukraine on Physical Education and Sport, 03150, Kyiv, Fizkul'tury str., 1. education of primary school age children. Journal of Education, Health and Sport. [Internet] 2018;8(6): 469-477. Available from: http://www. ojs.ukw.edu.pl/index.php/johs/article/view/6579 doi: 10.22141/2224-0551.13.1.2018.127059

13. Kashuba V, Futornyi S, Andrieieva O, Goncharova N, Carp I, Bondar O \& Nosova N. Optimization of the Processes of Adaptation to the Conditions of Study at School as a Component of Health Forming Activities of Primary School-Age Children. Journal of Physical Education and Sport (JPES) [Internet] 2018;18(4):2515. Available from: http:// efsupit.ro/images/stories/decembrie2018/Art\%20 377.pdf DOI:10.7752/jpes.2018.04377

14. Futornyi S. Actual issues of improving the process of students physical education through the application of modern health-saving technologies. Молодіжний науковий вісник Східноєвропейського національного університету імені Лесі Українки. Фізичне виховання і спорт. 2014; $14: 26-30$

15. Futornyi Serhii, Maslova Olena, Shmatova Olena, Osadcha Oksana, Rychok Tatiyana, Hopey Maksym, Tarnavskiy Artur Modern aspects of the ecological culture implementation in the physical education process of different population groups. Journal of Physical Education and Sport (JPES). [Internet] 2020 Jen [cited 2020 March 2]; 20(1):348-353. Available from: https://efsupit. ro/images/stories/februarie2020/Art\%2049.pdf DOI:10.7752/jpes.2020.s1049

Надійшла 18.08.2020 